\title{
PEMBERDAYAAN EKONOMI MASYARAKAT MELALUI \\ PROGRAM PKM UNTUK MENINGKATKAN KAPASITAS \\ PRODUKSI PERMEN JELLY BUAH DAN JELLY SAYURAN \\ DI KOTA MALANG
}

\author{
Zainul Arifin 1); Istutik $^{2)}$; Anang Amir Kusnanto ${ }^{3)}$ \\ Dosen STIE Malangkuçeçwara Malang \\ Email:zainularifinabm@gmail.com; istutik@stie-mce.ac.id; amirkusnanto@gmail.com.
}

\begin{abstract}
Candy is a snack that is loved by children and adolescents, because it tastes sweet, has a distinctive aroma and is affordable. Many types of candy both made from artificial ingredients and from natural ingredients. Specially soft and chewy jelly candy is much loved by young people. A businessman partner named Dian Falah Fitriyana, ST is located at Jl. Ikan Hiu II / 19 Tunjungsekar Village, Lowokwaru District, Malang City innovates by producing jelly candy from fruit raw materials (apple jelly candy and dragon fruit jelly candy) and made from vegetable raw materials (Moringa jelly candy and carrot jelly candy). As it is known that apples, dragon fruit and vegetable Moringa and carrots have many health benefits. Raw material for jelly candy is only taken from the juice and not added with preservatives. The purpose of the PKM program is to increase the production capacity of partner entrepreneurs and provide online marketing training, training and accounting assistance, so that partner entrepreneurs can make financial reports needed for a productive business. The problem of micro entrepreneurs in general is not being able to increase their production because of limited capital, which has the effect of not being able to add or replace their more modern production facilities. Marketing limitations and not doing financial records properly. The Community Partnership Program (PKM), which provides production support equipment and management improvements, will certainly increase production output

The solutions offered by the PKM program to increase the production capacity of partner entrepreneurs are to provide juicers, sterilitators, sealers, digital scales, LPG ovens, containers, trays, containers. Meanwhile, to improve financial management and product marketing, the Team provides training and mentoring in accounting and marketing training. It is expected that partner entrepreneurs are able to make financial records (cash flow) and market their products through internet marketing. Partner entrepreneurs with the help of new equipment from the PKM program are targeting production to increase by $50 \%$ to $100 \%$. This optimistic target is achieved due to juice, sterilitators, chopper machines, large ovens and more modern production facilities, entrepreneurs will be able to serve the demands of more consumers. The progress of PKM program activities has reached $70 \%$ of the target, but there are still activities to assist in making financial reporting and online marketing.
\end{abstract}

Keywords: Carrot Jelly Candy, Apple Jelly Candy 


\begin{abstract}
ABSTRAK
Permen merupakan makanan ringan yang sangat disukai anak-anak dan remaja, karena rasanya manis, aromanya khas dan harganya terjangkau. Banyak jenis permen baik yang terbuat dari bahan buatan maupun dari bahan alami. Khusus permen jelly yang bertekstur lembut dan kenyal banyak disukai anak muda. Pengusaha mitra yang bernama Dian Falah Fitriyana, ST beralamat di Jl. Ikan Hiu II/19 Kelurahan Tunjungsekar, Kecamatan Lowokwaru, Kota Malang berinovasi dengan memproduksi permen jelly dari bahan baku buah (permen jelly apel dan permen jelly buah naga) dan berbahan baku sayur (permen jelly kelor dan permen jelly wortel). Seperti diketahui bahwa buah apel, buah naga dan sayur kelor dan wortel banyak manfaatnya bagi kesehatan. Bahan baku permen jelly ini hanya diambil sarinya dan tidak ditambahi bahan pengawet. Tujuan program PKM ini adalah untuk meningkatkan kapasitas produksi pengusaha mitra dan memberikan pelatihan pemasaran secara online, pelatihan dan pendampingan akuntansi, sehingga pengusaha mitra dapat membuat laporan keuangan yang diperlukan bagi suatu usaha produktif. Permasalahan pengusaha mikro pada umumnya tidak mampu meningkatkan produksinya karena keterbatasan modal, yang berdampak tidak mampu menambah atau mengganti fasilitas produksinya yang lebih modern. Keterbatasan pemasaran dan tidak melakukan pembukuan keuangan dengan baik. Program Kemitraan Masyarakat (PKM) yang memberikan hibah peralatan penunjang produksi dan pembenahan manajemen dapat dipastikan akan meningkatkan hasil produksi Solusi yang ditawarkan program PKM untuk meningkatkan kapasitas produksi pengusaha mitra yaitu memberikan juicer, sterilitator, sealer, timbangan digital, oven LPG, container, loyang, kemasan. Sedangkan untuk membenahi manajemen keuangan dan pemasaran produk, Tim memberikan pelatihan dan pendampingan akuntansi dan pelatihan marketing. Diharapkan pengusaha mitra mampu membuat pencatatan keuangan (cash flow) dan memasarkan hasil produk melalui internet marketing. Pengusaha mitra dengan bantuan peralatan baru dari program PKM mentargetkan produksi akan meningkat 50\% sampai dengan 100\%. Optimis target ini tercapai disebabkan juice, sterilitator, mesin perajang, oven besar dan fasilitas produksi lebih modern, pengusaha akan mampu melayani permintaan konsumen yang lebih banyak. Kemajuan kegiatan program PKM ini sudah mencapai $70 \%$ dari target, tetapi masih ada kegiatan pendampingan pembuatan pelaporan keuangan dan pemasaran online.
\end{abstract}

Kata kunci: Permen Jelly Wortel, Permen Jelly Apel

\title{
PENDAHULUAN
}

Masyarakat mengenal banyak permen dengan berbagai jenis, baik yang di produksi pabrikan maupun dibuat UMKM. Permen digemari banyak orang karena rasa, teksturnya dan harga yang terjangkau. Khusus permen jelly yang bertekstur lembut dan kenyal banyak disukai anak muda. Pengusaha mitra yang bernama Dian Falah Fitriyana, ST beralamat di Jl. Ikan Hiu II/19 Kelurahan Tunjungsekar, Kecamatan Lowokwaru, Kota Malang berinovasi dengan memproduksi permen jelly dari bahan baku buah (permen jelly apel dan permen jelly buah naga) dan berbahan baku sayur (permen jelly kelor dan permen jelly wortel). Seperti 
diketahui bahwa buah apel, buah naga dan sayur kelor dan wortel banyak manfaatnya bagi kesehatan. Bahan baku permen jelly ini hanya diambil sarinya dan tidak ditambahi bahan pengawet. Seperti pada umumnya persoalan pengusaha usaha kecil menengah mikro (UKMK) yang kesulitan meningkatkan kapasitas produksinya karena kekurangan modal dan kesulitan dalam pemasaran hasil produksinya. Akibatnya pengusaha tidak mampu membeli peralatan yang modern dan tampilan packing masih sederhana, sehingga kurang menarik konsumen. Selain itu, tidak mempunyai kemampuan dalam melakukan pembukuan sehingga tercampur antara uang untuk kebutuhan rumah tangga dan untuk keperluan usaha.

Tujuan Program Kemitraan Masyarakat (program PKM) adalah untuk meningkatkan kapasitas produksi pengusaha mitra, memberikan pelatihan pemasaran secara online, pelatihan manajemen UMKM, pelatihan dan pendampingan akuntansi, sehingga pengusaha mitra dapat membuat laporan keuangan yang diperlukan bagi suatu usaha produktif. Analisis situasi pengusaha mitra dengan berbagai persoalan yang mungkin timbul, dan solusi pemecahan masalah akan diuraikan di bawah ini.

\section{Produksi}

Pengusaha mitra dalam membuat permen jelly apel dan buah naga, bahan bakunya yaitu buah apel dan buah naga. Sedangkan untuk membuat permen jelly kelor dan wortel, bahan bakunya dari sayur kelor dan wortel. Pengusaha mitra mempunyai 4 macam produk yaitu produk permen jelly apel, permen jelly buah naga, permen jelly kelor dan permen jelly wortel. Produk permen jelly ini telah mendapatkan izin dari Dinas Kesehatan dengan nomor registrasi P-IRT No. 209357301105. Keempat macam jenis permen jelly ini dapat dilihat pada gambar 1 .

\section{Gambar 1: Permen Jelly Apel, Permen Jelly Buah Naga dan Permen Jelly Wortel}

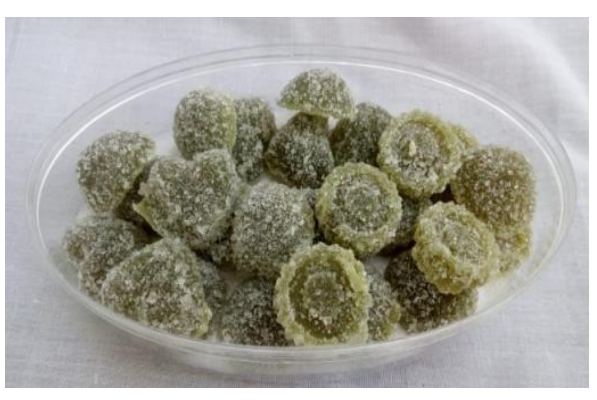

Permen Jelly Apel

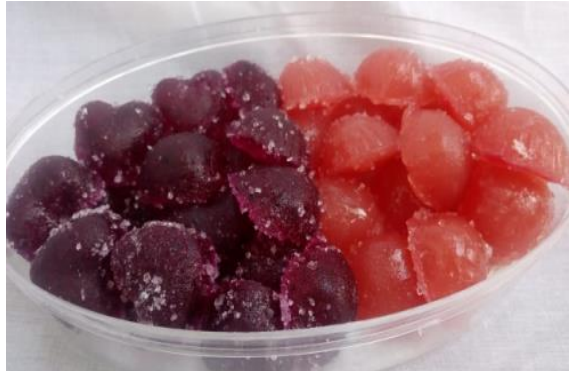

Permen Jelly Buah Naga 


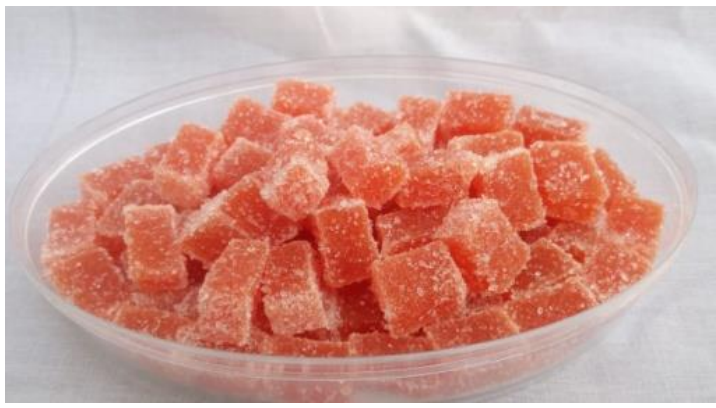

Permen Jelly Wortel

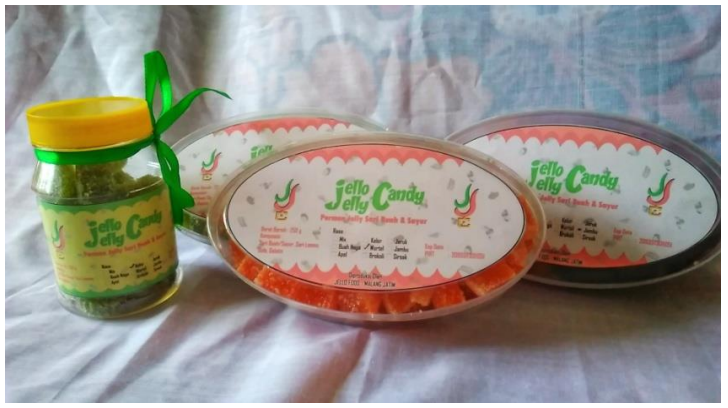

Permen Jelly Setelah di Packing

\section{Tenaga Kerja}

Pengusaha mitra dalam memproduksi permen jelly seperti pada umumnya pengusaha kecil mempekerjakan keluarganya dan masyarakat sekitar. Pengusaha mitra mempekerjakan 2 orang tenaga kerja. Pertumbuhan usaha kecil menengah sangat diperlukan bagi perekonomi Indonesia, karena akan banyak menyerap tenaga kerja. Semetara ini masih banyak tenaga terdidik baik tingkat SLTA maupun perguruan tinggi yang menganggur. Dari hasil penelitian diperolah kesimpulan bahwa pengembangan UKMK di Kabupaten Ngawi mampu menjadi faktor pendorong pertumbuhan ekonomi daerah serta membawa dampak positif terhadap penyerapan tenaga kerja...(Hasri, B. Santoso, Sigit dan Santoso, Djoko. 2012)

\section{Omzet Penjualan}

Penambahan peralatan produksi tentunya harus berkorelasi dengan penambahan omzet penjualan. Omzet penjualan pengusaha mitra dengan 4 macam produk permen jelly dalam satu minggu sebanyak $10 \mathrm{~kg}$. Atau dalam satu bulan omzet penjualan permen jelly rata-rata sebesar 40kg@Rp. $110.000=$ Rp.4.400.000.

\section{Pemasaran}

Daerah pemasaran produk permen jelly apel, permen jelly buah naga, permen jelly kelor dan permen jelly wortel di Kabupaten Malang dan Surabaya. System pemasaran yang dilakukan berdasarkan pesanan dari teman, keluarga dan kolega lainnya. Selain itu, dipasarkan secara online melalui media sosial. Hal ini disebabkan hasil produksi permen jelly masih terbatas.

\section{Permasalahan Mitra}

Setelah diidentifikasi dapat diketahui permasalah pengusaha mitra sebagai berikut: (a) Pengusaha mitra tidak dapat meningkatkan kapasitas produksinya, karena peralatan yang 
dimiliki kapasitasnya kecil dan belum dimiliki alat sterilitator; (b) Pengusaha mitra tidak melakukan pencacatan keuangan, hal ini akan mengakibatkan bercampurnya antara modal usaha dengan uang rumah tangga; (c) Masih kurangnya promosi pemasaran produknya baik melalui media cetak maupun media elektronik; dan (d) Kemasan hasil produksinya hanya menggunakan botol platik dan kotak plastik dengan ditempeli stiker yang tampilannya kurang menarik minat konsumen.

\section{METODE PELAKSANAAN}

\section{Tahapan Pelaksanaan Program Kemitraan Masyarakat}

Permasalahan yang dihadapi pengusaha kecil beraneka macam, terutama terkendala dengan terbatasnya modal usaha, kurang inovatif, jiwa wirausaha yang masih lemah dan pemasaran yang terbatas. Hasil penelitian menjelaskan bahwa berkaitan dengan berbagai masalah UMKM, maka diperlukan strategi untuk mengatasinya. Untuk mengembangkan UMKM tentu saja tidak hanya dibebankan pada UMKM sendiri, namun harus memperolah dukungan seluruh stake-holders. Dukungan termasud diharapkan datang dari asosiasi pengusaha, perguruan tinggi dan atau dinas/instansi terkait di lingkungan pemerintah kabupaten/kota dan Provinsi (Hamid, S, E dan Susilo, Y S. 2011:54).

Tahapan pelaksanaan kerja untuk menyelesaikan permasalahan pengusaha mitra adalah sebagai berikut: (a) Penyediaan fasilitas produksi dengan kapasitas besar dan modern; (b) Pelatihan internet maketing; (c) Pelatihan Manajemen UMKM; (d) Pelatihan akuntansi; dan (e) Pendampingan pembuatan laporan keuangan. 


\section{Gambar 2: Metode Pelaksanaan}

\section{Tahapan Keria Program PKM}

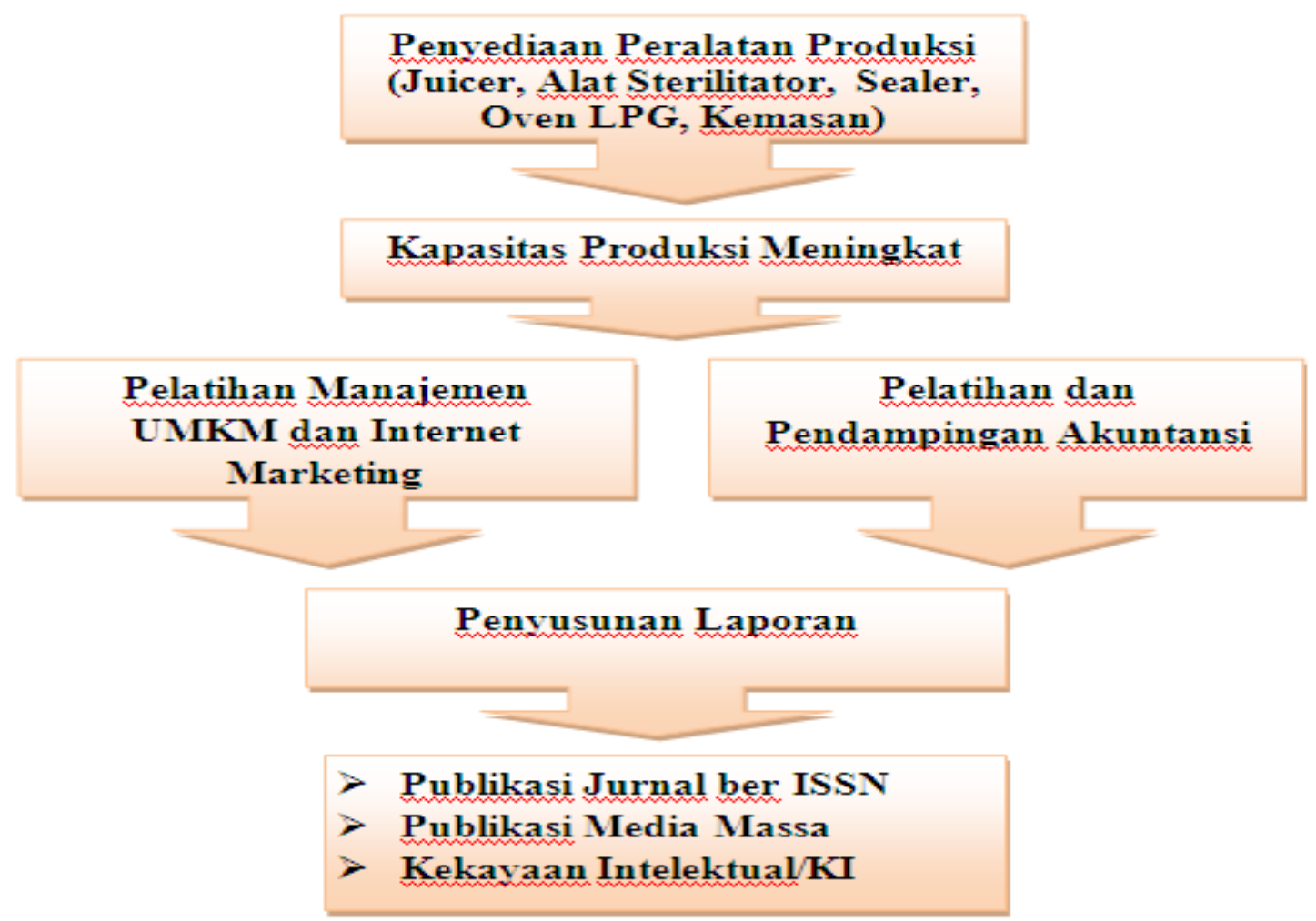

\section{Iptek yang akan Ditransfer}

Iptek yang akan ditransfer kepada pengusaha mitra antara lain: (a) Pengusaha mitra mempunyai pengetahuan dalam membuat laporan keuangan dan mampu mengoperaskan software akuntansi sederhana; (b) Pengusaha mitra mampu meningkatkan kapasitas produksinya dengan adanya peralatan produksi yang berkapasitas besar dan modern; (c) Pengusaha mitra mampu meningkatkan omzet penjualan dengan melakukan pemasaran secara langsung dan pemasaran secara online; dan (d) Dengan adanya packing produk yang baru akan lebih menarik konsumen untuk membeli.

Penyediaan peralatan produksi sangat diperlukan bagi pengusaha kecil untuk meningkatkan kapasitas produksinya, sekaligus meningkatkan omzet penjualannya. Dengan peralatan yang baru dan pelatihan akuntansi serta pendampingan pembuatan laporan keuangan, pengusaha mitra lebih meningkatkan kapasitas produksinya dan area pemasarannya (Kusnanto, AA. dan Supriyanto. 2015:57). 


\section{Gambar 3: Iptek yang akan Ditransfer kepada Pengusaha Mitra}

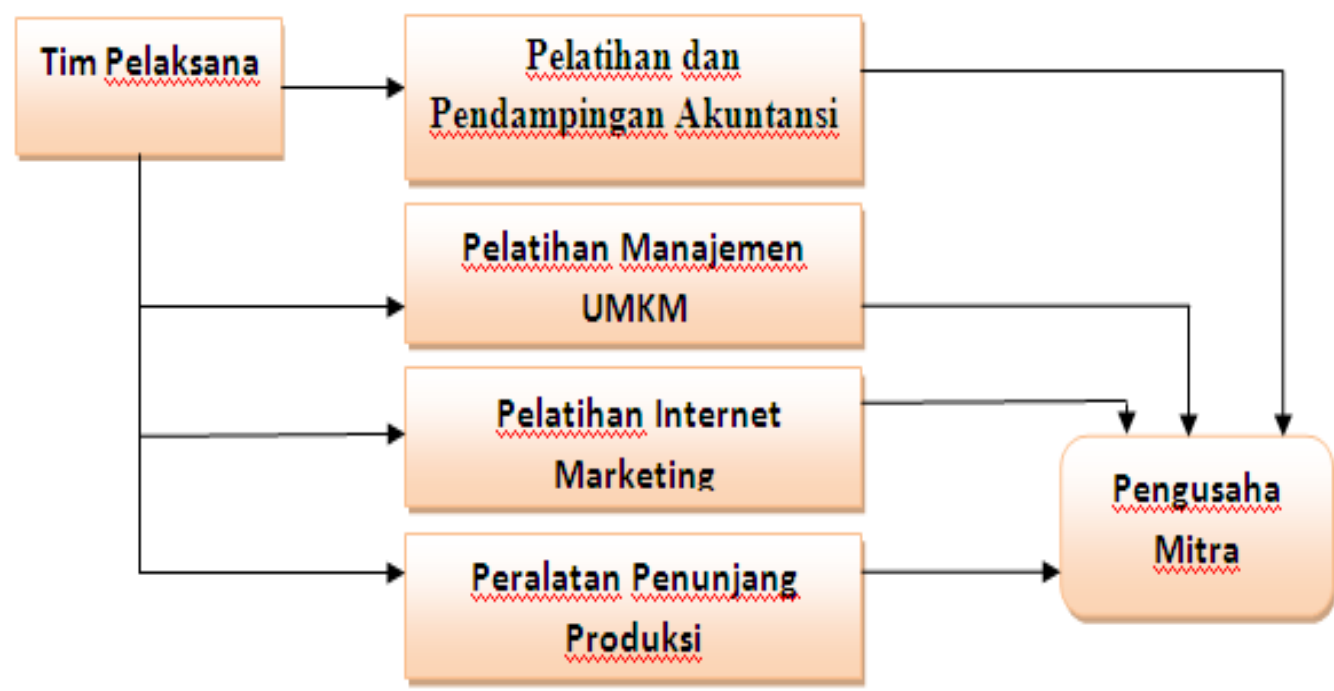

\section{HASIL CAPAIAN}

Pelaksanaan kegiatan program PKM yang dilaksanakan tim mulai dari penyediaan peralatan produksi, pelatihan manajemen UKMK, pelatihan internet marketing, pelatihan akuntansi dan pendampingan pembuatan laporan keuangan, akhirnya bermuara pada peningkatan hasil produksi dan peningkatan omzet penjualan. Pada tahap berikutnya meningkatkan keuntungan pengusaha mitra.

Hasil capaian sebalum dan sesudah pelaksanaan program PKM adalah sebagai berikut:

a) Sebelum program PKM pengusaha mitra melakukan pejualan hanya melalui pesanan dan kebanyakan dari Kota Surabaya, tetapi setelah program PKM pengusaha mitra mulai memasarkan melalui online, konsinyasi dan bedasarkan pesanan.

b) Sebelum program PKM pengusaha mitra belum melakukan pembukan keuangan, tetapi setelah program PKM pengusaha mitra sudah mulai mencatat pembukuan keuangan melalui software akuntansi sederhana.

c) Sebelum program PKM kemasan produk menggunakan toples plastik dengan label stiker, tetapi setelah program PKM kemasan menggunakan plastik foil dengan label yang didesain dengan baik.

d) Sebelum program PKM omzet penjualan pengusaha mitra dengan 4 macam jenis permen jelly dalam sebulan rata-rata sebesar 40 kg @ Rp. $110.000=$ Rp. 4.400.000, setelah program PKM dengan penambahan peralatan produksi dan perluasan jaringan 
pemasaran pada bulan Agustus tercatat penjualan permen jelly sebanyak 55 kg @ Rp. $110.000=$ Rp. 6.050.000 atau naik 37.5\%. Diperkiakan mulai bulan Oktober dan November 2019 sudah melayani permintaan dari koperasi sekolah/pesantren.

e) Sebelum program PKM pengusaha mitra belum mempunyai peralatan produksi yang memadai (kapasitas kecil), tetapi setelah program PKM diberikan peralatan yang modern dan berkapasitas besar seperti juicer, sealer, alat strerilitator dan oven.

Rekapitulasi hasil capaian pelaksanaan program PKM dapat dilihat pada tabel berikut.

\section{Tabel : Capaian Hasil Pelaksanaan Program PKM}

\begin{tabular}{|c|l|l|}
\hline NO & \multicolumn{1}{|c|}{ SEBELUM PROGRAM PKM } & \multicolumn{1}{c|}{ SETELAH PROGRAM PKM } \\
\hline 1 & $\begin{array}{l}\text { Pengusaha mitra melakukan penjualan } \\
\text { permen jelly berdasarkan pesanan }\end{array}$ & $\begin{array}{l}\text { Pengusaha mitra selain penjualan permen } \\
\text { jelly berdasarkan pesanan, juga melalui } \\
\text { konsinyasi dan } \text { online. }\end{array}$ \\
\hline 2 & $\begin{array}{l}\text { Pengusaha mitra belum melakukan } \\
\text { pembukuan secara tertib }\end{array}$ & $\begin{array}{l}\text { Pengusaha mitra sudah mulai melakukan } \\
\text { pembukuan keuangan melalui software } \\
\text { akuntansi sederhana }\end{array}$ \\
\hline 3 & $\begin{array}{l}\text { Kemasan produk menggunakan toples } \\
\text { plastik dengan label dari stiker }\end{array}$ & $\begin{array}{l}\text { Kemasan sudah menggunakan plastik foil } \\
\text { dengan label yang didesain baik. }\end{array}$ \\
\hline 4 & $\begin{array}{l}\text { Omzet penjualan dengan 4 macam } \\
\text { produk permen jelly per bulan rata-rata } \\
\text { sebanyak 40 kg @ Rp. 110.000 = Rp. } \\
4.400 .000,-\end{array}$ & $\begin{array}{l}\text { Dengan adanya peralatan modern omzet } \\
\text { penjualan pada bulan Agustus sebanyak } \\
\text { 55 kg @ Rp. 110.000 = Rp. 6.050.000, } \\
\text { atau naik sebesar 37,5\%. }\end{array}$ \\
\hline 5 & $\begin{array}{l}\text { Pengusaha mitra belum mempunyai } \\
\text { peralatan juicer, sterilitator, oven dan } \\
\text { sealer. }\end{array}$ & $\begin{array}{l}\text { Pengusaha mitra sudah mempunyai } \\
\text { peralatan juicer, sterilitator, oven dan } \\
\text { sealer. }\end{array}$ \\
\hline
\end{tabular}

Sebelum konsumen merasakan permen jelly, tentu yang dilihat pertama kali yaitu kemasannya. Kemasan yang higienis dan didesain baik akan menarik minat konsumen untuk membeliya. Kemasan menggunakan bahan plastik foil dengan desain khusus, selain kelihatan mewah juga lebih tahan lama. Perbedaaan kemasan produk permen jelly sebelum dan setelah program PKM dapat dilihat pada gambar berikut. 


\section{Gambar 4: Kemasan Permen Jelly Sebelum Program PKM}

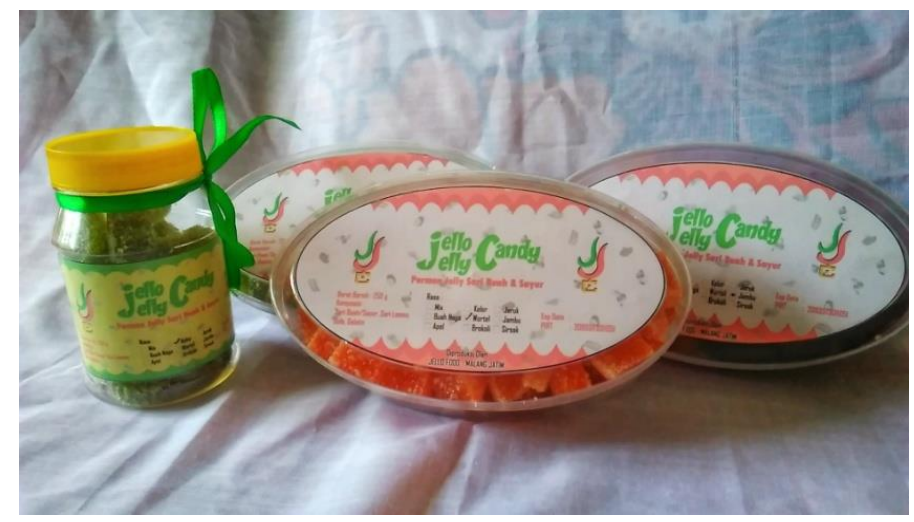

\section{Gambar 5: Kemasan Permen Jelly Setelah Program PKM}
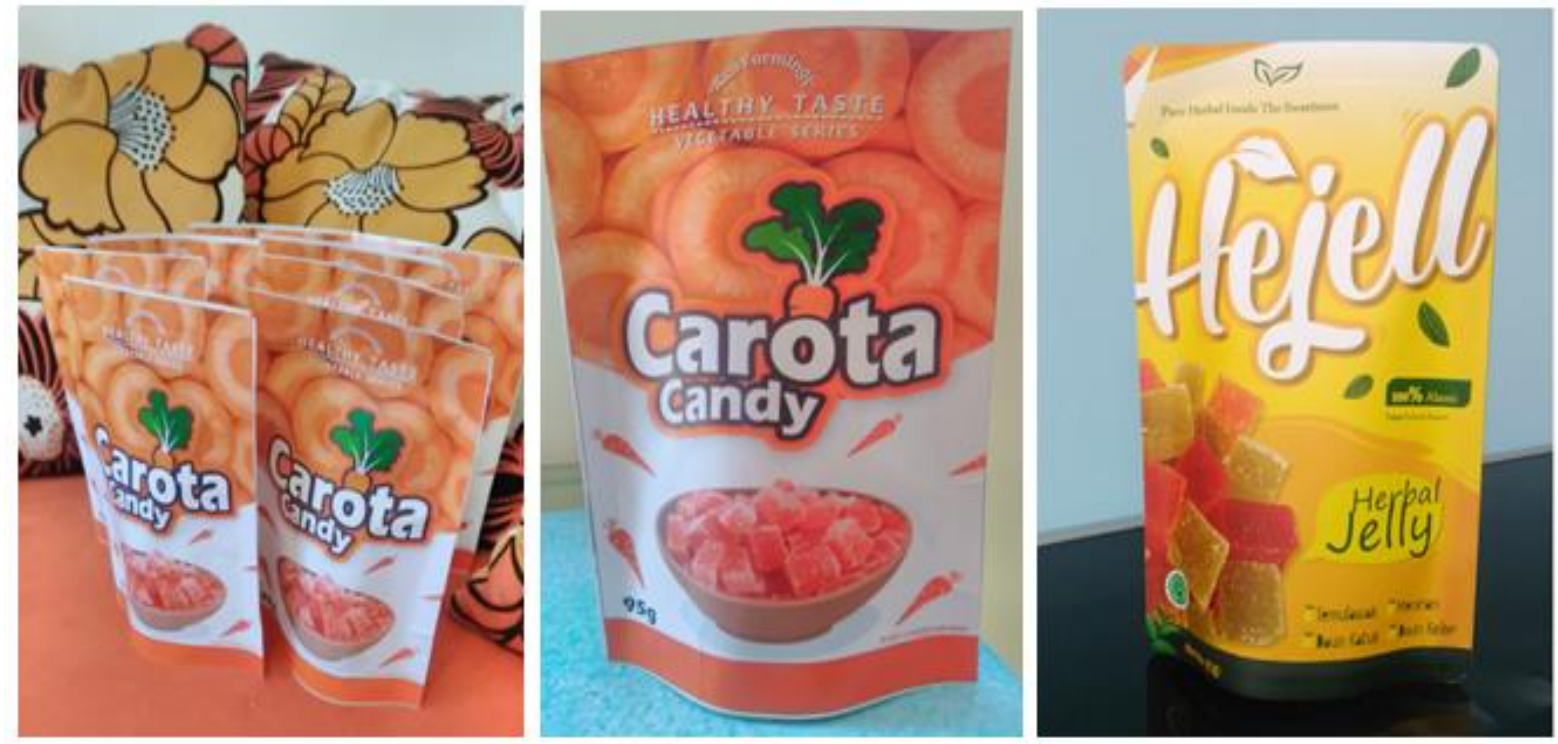

Program PKM selain bertujuan meningkatkan kapasitas produksi pengusaha mitra, juga untuk neningkatkan pengetahuan dan jaringan pemasaran hasil produksinya. Oleh sebab itu, perlu adanya berbagai pelatihan untuk mendukung maksud tersebut di atas. Kegiatan pelatihan manajemen UMKM, pelatihan internet marketing, pelatihan akuntansi dapat dilihat pada gambar berikut. 


\section{Gambar 6: Pelatihan Internet Marketing, Pelatihan Manajemen UMKM dan Pelatihan Akuntansi}
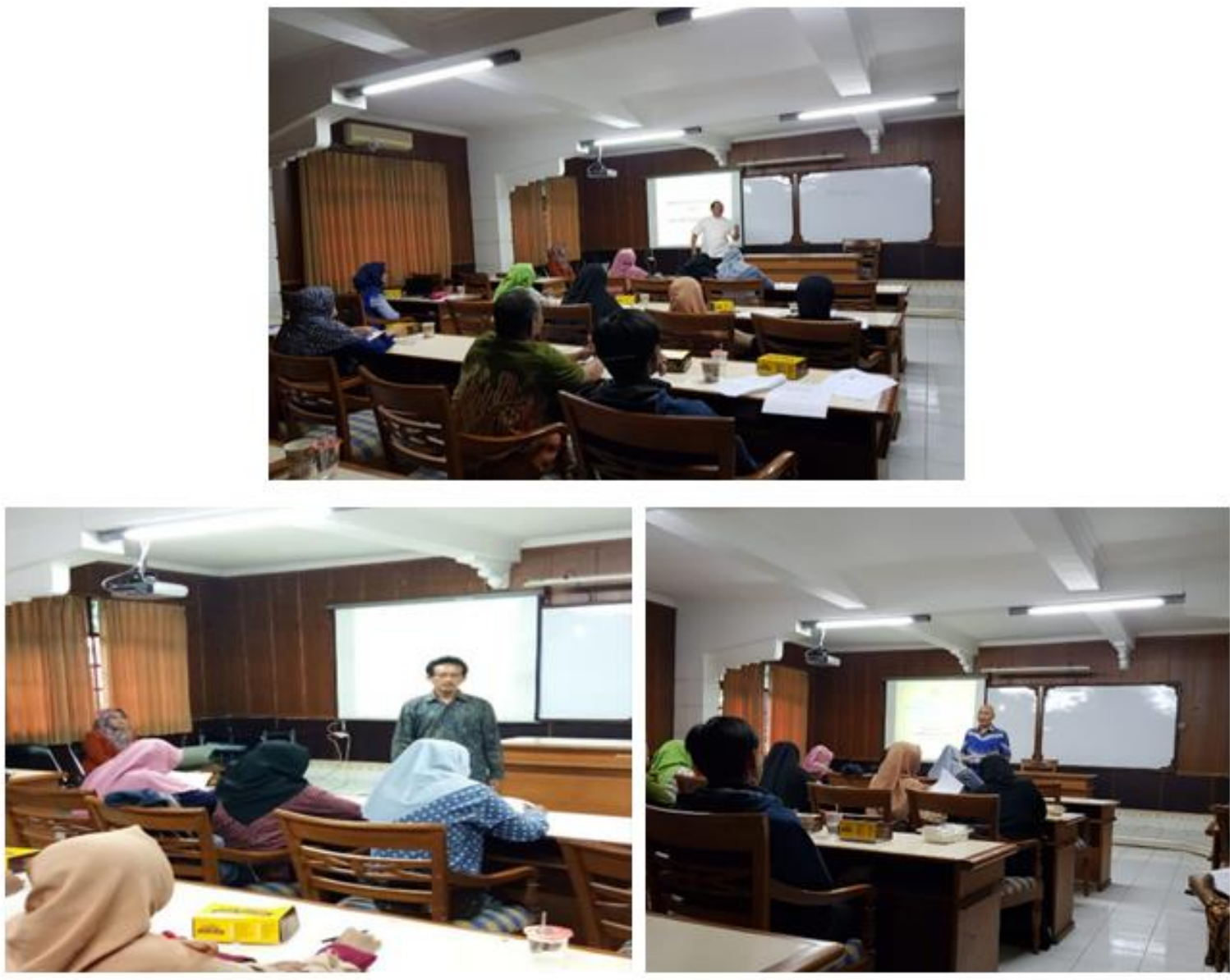

Dengan demikian nyata bahwa pengusaha UKMK perlu uluran tangan pemerintah melalui instansi terkait untuk membantu peralatan, manajemen, pemasaran dengan mengikutkan pameran-pameran untuk memperkenalkan dan sekaligus menjual hasil produksinya. Semakin banyak pengusaha UMKM yang berkembang usahanya, akan semakin baik dari sisi penyerapan tenaga kerja dan peningkatan pendapatan masyarakat. Di sini peran strategis pemerintah dalam memajukan usaha UMKM di Indonesia.

Kebanyakan pelaku usaha mikro mempunyai persoalan yang hampir sama yaitu kekurangan modal untuk membeli peralatan yang dibutuhkan guna meningkatkan kapasitas produksinya. Dalam program PKM solusi yang diberikan dengan memberikan peralatan yang dibutuhkan (Kusnanto, AA dan Hariadi, S. 2018) 


\section{KESIMPULAN}

1. Bantuan hibah dari Menristek Dikti melalui program PKM ini sangat bermanfaat bagi pengusaha mitra untuk meningkatkan kapasitas produksi dan omzet penjualannya.

2. Sebelum program PKM omzet penjualan dengan 4 macam produk permen jelly per bulan rata-rata sebanyak 40 kg @ Rp. $110.000=$ Rp. 4.400.000,- Setelah program PKM dengan adanya peralatan modern omzet penjualan pada bulan Agustus sebanyak 55 kg@ Rp. $110.000=$ Rp. 6.050.000, atau naik sebesar 37,5\%.

3. Pelatihan manajemen, pelatihan internet marketing dan pelatihan akuntansi menambah wawasan pemikiran pengusaha mitra untuk memanej usahanya dengan baik dan menambah luas jaringan pemasaran produksinya.

4. Semangat ingin maju menjadi sangat penting bagi pengusaha UMKM, jika menginginkan usahanya maju. Mengubah mainset pengusaha perlu dilakukan mengingat masih banyak pengusaha yang berusaha apa adanya.

\section{DAFTAR PUSTAKA}

Hamid, SE, dan Susilo, YS. 2011. Strategi Pengembangan Usaha Mikro Kecil Menengah di Provinsi Daerah Isimewa Yogyakarta. Jurnal Ekonomi Pembangunan. Volume 12. Nomor 1. Hal. 45-55.

Hasri B., Sigit, S. dan Santoso. D. 2012. Analisis Pengembangan Usaha Kecil Menengah untuk Meningkatkan Pertumbuhan Ekonomi Sebagai Upaya Pengentasan Kemiskinan dan Pengangguran Daerah di Kabupaten Ngawi. http://jurnal.fkip.uns.ac.id/index.php/s2ekonomi/article/view/6947/4739. Diakses tanggal 12 Juni 2017.

Kusnanto, AA. dan Supriyanto. 2015. Kemitraan Perguruan Tinggi dengan Pengusaha KecilMenengah untuk Meningkatkan Kapasitas Produksi Melalui bantuan Sarana Produksi, Teknologi Informasi dan Pendampingan Pembuatan Laporan Keuangan. Jurnal ABM- Mengabdi. Volume 2 Hal. 51-57.

Kusnanto, AA. dan Hariadi, S. 2018. Program Kemitraan Masyarakat Pacu Peningkatan Produktivitas Pengusaha Manisan di Kota Malang dan Kota Batu. Vol. 2 No. 1. http://ojs.unik-kediri.ac.id/index.php/jaim/article/view/238. Diakses tanggal 23 September 2019. 